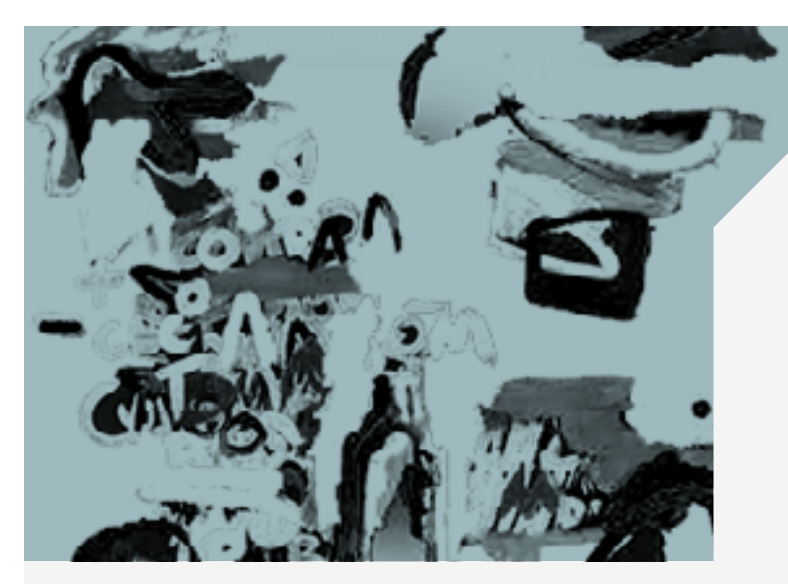

\title{
AS NARRATIVAS DE ESCRAVOS E A CONSTRUÇÃO DA IDENTIDADE COLETIVA DO OUTRO AFRO-AMERICANO
}

SLAVE NARRATIVES AND THE CONSTRUCTION OF COLECTIVE IDENTITY OF THE OTHER AFRICAN-AMERICAN

Débora Spacini Nakanishi*

RESUMO: Este trabalho pretende elucidar a construcão da identidade do afro-americano a partir da imagem do Outro, imposta aos es作 de escravos. Tais textos, produzidos pelos próprios, mostram-se um esforço para recusar a imagem do Outro e humanizálos. Faremos, primeiramente, um breve panorama do sistema escravagista estadunidense para que possamos compreender como ele desumaniza o homem negro, apoiando-nos em autores como Gates Jr.e McKay (2004) e Coombs (2008). Em seguida, procuramos entender as motivações para a produção das narrativas de escravos e como elas contribuem com a construçáo da identidade coletiva do escravo. Baseamo-nos em autores como Olney (1984), Bauer (2015), Roy (2015), entre outros. Faremos, finalmente, uma rápida análise de 12 anos de escravidão, procurando explicitar as especificidades da autobiografia de Solomon Northup, pertencente ao gênero, mas que se faz única de diversas maneiras.

PALAVRAS-CHAVE: Narrativas de escravos; literatura afro-americana sistema escravagista; 12 anos de escravidão. * debora.nakanishi@gmail.com
Mestre e doutoranda em Letras pelo Programa de Pós-graduação
em Letras da Universidade Estadual Paulista (Unesp), campus de São
José do Rio Preto (Ibilce). ORCID 0000-0001-9316-6197.

ABSTRACT: This paper aims to elucidate the construction of the identity of the African $A$ the slaves of the United States in the nineteenth century, through the narratives of slaves. Such texts, produced by the slaves themselves, show an effort to reject the image of the Other and humanize them. We will first provide a brief overview of the American slavery system so that we can understand how it dehumanizes the black man, by relying on such authors as Gates Jr. and McKay (2004) and Coombs (2008). Next, we try to understand the motivations for the production of slave narratives and how they contribute to the construction of the collective identity of the slave. We base our observations on authors such as Olney (1984), Bauer (2015), Roy (2015), among others. Finally, we will make a quick analysis of 12 Years a Slave, trying to explain the specificities of Solomon Northup's autobiography, which belong to the genre, but is unique in many ways.

KEYWORDS: Slave narratives; African American Literature; slavery system; 12 Years a Slave. presente trabalho foi realizado com a poio do CNPq, Conselho Nacional de Desenvolvimento Científico e Tecnológico - Brasil. 
1. GATES Jr.; MCKAY. The Norton anthology of African American literature, p. 154

\section{NTRODUÇÃO: UMA BREVE CONTEXTUALIZAÇÃO DO}

\section{ESCRAVO NA HISTORIA ESTADUNIDENSE}

É de conhecimento geral que a escravidão vem de muito antes da descoberta das Américas, sendo encontrada em variadas épocas e nas mais variadas formas, desde os hebreus no Egito, aos povos de diversas etnias em Roma e, até mesmo, em tribos na África. De acordo com Gates Jr. e McKay (2004):

Um historiador autodidata, David Walker, reconheceu que a escravidão já era praticada na África há muito tempo, mas acusou os escravocratas cristãos brancos de crimes maiores contra a humanidade e ainda maior hipocrisia ao justificar esses crimes dos quais foram culpados do que qualquer outro sistema escravocrata anterior. Estudiosos do século $\mathrm{XX}$ apoiaram as alegações de Walker e de outros da vanguarda afro-americana antiescravagista, de que a escravidão, na forma perpetuada pelos colonizadores europeus da África e das Américas, levou a desumanidade a um nível de eficiência tecnológica como nunca imaginada pelas gerações anteriores.

Em todo sistema escravagista, o escravo é propriedade do dono, mas, nas Américas, esse conceito é levado a um nível mais profundo. Coombs (2008) afirma que o sistema escravagista nas Américas se diferencia dos demais por três elementos: capitalismo, individualismo e racismo. Tais elementos contribuem para a imagem do escravo como o Outro na sociedade estadunidense. Começa remos, portanto, refletindo sobre o capitalismo e depois passa remos para os dois elementos seguintes.

Como já dito, Gates Jr. e McKay compreendem a desumanização como marca registrada dos sistemas escravocratas das Américas. Os críticos corroboram a concepção de Coombs, que também mantém a desumanização provocada pelo sistema. Isso porque o capitalismo torna o escravo muito mais do que propriedade, transformando-o em capital. Ele é um investimento que o senhor faz em sua plantação, da mesma forma como ele investiria em novos instrumentos ou terras; ou seja, o escravo é um ativo da fazenda. Além disso, ele é um produto valioso, servindo como moeda de troca no comércio ou mesmo como espólio para próximas gerações da família proprietária. Com o interesse em aumentar seu capital, muitos senhores ta mbém forçam os escravos a se reproduzirem como animais, uma vez que o recém-nascido se torna automaticamente parte da fazenda.

A cobiça capitalista é tamanha que torna o próprio sistema escravagista facilmente maleável, moldando-o conforme os interesses mudam. Gates Jr. e McKay afirmam que os primeiros negros trazidos da África não são escravos

EM TESE BELO HORIZONTE $\quad$ v. $24 \quad$ N. 2 MAIO-AGo. 2018 NAKANISHI. As narrativas de escravos e a construção da identidade [...] $\quad$ P. 82-100

Teoria, Crítica Literária, outras Artes e Mídias 
2. GATES Jr.; MCKAY. The Norton anthology of African American
literature, p. 155. e que essa condição só lhes é imposta porque os donos de fazendas sentem a necessidade de fazê-lo:

Eles eram classificados como servos contratados que poderiam se tornar livres se trabalhassem satisfatoria mente para seus senhores por um número determinado de anos. Mas, por volta de 1700, o crescimento da economia das plantations de Virgínia exigia uma força de trabalho mais barata que o trabalho livre e mais facilmente controlável. ${ }^{2}$

Essa mudança drástica da classificação, de servo contratado para escravo sem direitos, é indício do quão forte é a influência do capitalismo nesse sistema escravocrata, pois o interesse econômico encontra-se acima dos princípios do próprio sistema. A partir de então, o comércio de escravos torna-se altamente lucra tivo, trazendo mais de $388 \mathrm{mil}$ negros de países africanos (de acordo com o The Abolition of the Slave Trade, site do grupo de pesquisa da biblioteca pública de Nova York).

Já o individualismo ganha força na época da Independência dos Estados Unidos. No auge do processo de independência da Grã-Bretanha, o homem branco norte-a mericano, dono de escravos, comete a maior hipocrisia: luta pela própria liberdade enquanto mantém outros cativos. Isso implica em um individualismo exacerbado, resultante do sonho democrático, que, para Coombs, segrega ainda mais o escravo, pois ele torna-se "inferior entre semelhantes", o Outro. O estabelecimento da democracia, associado ao capitalismo, exclui o escravo de vez da sociedade, pois agora, comprovadamente, destitui dele a humanidade. Em outras palavras, ele se torna menos do que um ser humano, posto que todos os humanos têm direito à liberdade:

De um ponto de vista lógico, a Declaração de Independência ou afirmava a liberdade do imigrante africano, ou negava sua humanidade. Visto que cada estado continuou quase como uma entidade soberana separada, a Declaração de Independência tornou-se uma abstração filosófica, e o status do africano na América foi determinado por cada estado. ${ }^{3}$

Coombs ainda explica que o individualismo da época está associado à democracia, pois o indivíduo sozinho pode prosperar por meio do próprio esforço (o sonho norte-americano que persiste até hoje). Este sonho nasce e baseia-se na Declaração de independência dos Estados Unidos, ratificado em 1776, que afirma a essência do país como um lugar de oportunidades, em que qualquer cidadão é livre para buscar a própria prosperidade. Por outro lado, Bosi (2010) a firma que a liberdade individual, defendida na época do sistema escravagista, é o liberalismo do proprietário. Dessa forma, somente alguém com bens pode ser um cidadão com voz na sociedade e, portanto, considerado um indivíduo único,
3. COOMBS. The shape of American slavery, s/p. 
4. BOSI. Ideologia e contraideologia, p. 28 . mesmo se pertencer a um grupo hegemônico, com interesses e objetivos em comum. O escravo, longe de ser um proprietário, é entendido como infra-humano. O sonho norte-americano da prosperidade individual não lhe pertence:

A liberdade individual (religiosa, política) só faz sentido quando lastreada pela posse de bens (terras, dinheiro) que fazem do indivíduo um cidadão. Fora da propriedade não há cidadania, pois o homem dependente (o servant, o assalariado) não tem condições objetivas nem subjetivas de participar da administração pública em nenhuma das suas esferas: o não proprietário não é livre, logo está fora do círculo da sociedade civil e do poder estatal. Assim, o individualismo lockiano não é absoluto nem universal: há indivíduos independentes e indivíduos dependentes. ${ }^{4}$

De modo similar, o racismo, terceiro elemento indicado por Coombs, segrega o escravo como nunca antes. O comércio de escravos nas Américas é feito a partir da África e a mercadoria africana é, portanto, negra. Isso torna o escravo invisível em sua visibilidade marcada pela cor da tez, condenando-o a ser visto como inferior, mesmo se, de alguma forma, conseguisse a liberdade. Ou seja, esse sujeito é impossibilitado de ascender socialmente e ganhar sua humanidade de volta porque a cor da pele marcá-lo-ia para sempre.
A liberdade tão desejada pelos escravos é estabelecida e legalizada na Constituição dos Estados Unidos da América (1787), visando garantir os direitos civis de seus cidadãos. Esses direitos, entretanto, não contemplam os escravos, pois sempre estiveram nas mãos dos brancos, que não os levam em consideração. Consequentemente, os escravos não têm direitos civis, nem direito a propriedade: "A lei claramente estabelecia que ele não podia possuir, herdar, nem se dedicar a compra e venda, exceto se fosse desejo do seu senhor" ${ }^{5}$ Apesar de algumas leis tentarem garantir o mínimo de humanidade no tratamento do escravo, sempre que os interesses do senhor e do escravo entram em choque, o primeiro tem preferência absoluta.

Além da privação em relação ao capital, aos bens da comunidade e à sua própria imagem, os escravos nos Estados Unidos são ensinados que a cultura africana é inferior e sem valor, e são forçados a negá-la (ou, pelo menos, a fingir negá-la). Acabam, assim, desprovidos de identidade e vistos como crianças carentes de educação. Portanto, o senhor cria uma figura paternal que demanda total dependência dos escravos, esperando deles um comportamento semelhante ao de crianças ante os comandos do pai: total obediência às regras ou punição. O Destino Ma nifesto, que afirma os norte-americanos como o povo mandado por Deus para povoar/ dominar/ expandir territórios, provoca
5. COOMBS. The shape of American slavery, s/p. 
6. COOMBS. The shape of American slavery, s/p.

7. GATES Jr.; MCKAY. The Norton anthology of African American anthology of Africa
literature, p. 151.

8. GATES Jr.; MCKAY. The Norton anthology of African American literature, p. 155 nos senhores, como consequência secundária, o desejo de moldar o caráter dos escravos, por serem parte da propriedade: "Em geral, havia cinco passos para moldar o caráter de tal escravo: disciplina rigorosa, senso de sua própria inferioridade, crença no poder superior do senhor, aceitação dos padrões do senhor e, finalmente, um profundo senso da própria impotência e dependência". ${ }^{6}$

Com essa tentativa de apagamento da identidade dos negros, a religião de matriz africana também é vista com maus olhos. O branco norte-america no, predomina ntemente cristão, rejeita as religiões africa nas diferentes da sua. $\mathrm{O}$ senhor, muitas vezes, acredita ser sua missão converter os escravos e impor-lhes a religião cristã. Entretanto, a hipocrisia mais uma vez predomina, pois, apesar de todos serem filhos de Deus, os negros ainda são inferiores aos brancos: "Quanto ao espírito, a maioria dos brancos estava satisfeita com as reivindicações do afro-americano a um direito igual à graça de Deus, desde que a salvação do afro-americano não implicasse uma redenção radical da ordem social dominada pelos brancos". 7 O escravo, assim, acaba por enfrentar uma "morte social" sendo forçado a desprender-se de toda a sua cultura e identidade, torna ndo-se uma “[... 'não-pessoa social', um ser que pela definição legal não poderia ter família, honra pessoal, comunidade, passado ou futuro". 8
Sem perspectivas, o escravo depende da boa vontade do senhor, que, muitas vezes, cria laços com alguns dos criados, especialmente os que desempenham bem o papel de servo. Os escravos mais talentosos conquistam postos importantes nas fazendas ou são alugados pa ra trabalhar em alguma oficina da vila. Por outro lado, os escravos que não desempenham bem seu papel são maltratados ou vendidos. Essa falta de espera nça, que domina a maior parte dos escravos, ajuda a construir, entre os proprietários, a imagem dos negros como pessoas preguiçosas. De acordo com Coombs (2008), entretanto, os escravos não se revelam preguiçosos, mas sim apáticos, justamente por não terem perspectivas de uma vida melhor. Há, ta mbém, a possibilidade de que essa falta de vontade de trabalhar seja uma forma de protesto "passivo": os escravos não trabalham mais do que precisam para sobreviver na fazenda, limitando o lucro do senhor.

Apesar de a $13^{\text {a }}$ Emenda ${ }^{9}$ garantir o fim da escravidão, o futuro dos ex-escravos no pós-guerra é incerto. Depois de um período tão longo de servidão e desumanização, os negros são deixados à própria sorte. Aos poucos, começam a integrar-se à sociedade, mas não sem muitas lutas e sofrimento. A história de escravidão deixa um legado de racismo tão intrínseco na sociedade norte-a mericana que, mesmo depois de dois séculos, ainda é possível afirmar que a cor da pele segrega pessoas no país ou diferencia o seu
9. A $13^{\mathrm{a}}$ Emenda à Constituição dos Estados Unidos proíbe, em exceto em caso de punição por crime cometido. Foi adotada oficialmente em 1865, após anos de tentativas de aprovação por parte do então presidente Abraham Lincoln.
EM TESE BELO HORIZONTE $\quad$ v. $24 \quad$ N. 2 MAIO-A60. 2018 NAKANISHI. As narrativas de escravos e a construção da identidade [...] $\quad$ P. 82-100

Teoria, Crítica Literária, outras Artes e Mídias 
modo de vida. Atualmente, o assunto ainda se mostra delicado, polêmico e pouco discutido pela sociedade norte-america na de uma maneira geral. Já nas universidades e no meio acadêmico, há uma discussão maior sobre a questão, inclusive na área de literatura. Praticamente todas as universidades norte-america nas possuem departamentos específicos, oferecendo disciplinas sobre história e literatura afro-a mericana, que contemplam ta mbém textos escritos pelos próprios escravos. Tais textos, como as autobiografias de ex-escravos, são parte fundamental da literatura norte-a mericana, como veremos a seguir. Entre eles, encontra-se 12 anos de escravidão, de Solomon Northup, que discutiremos adiante, procurando evidenciar as convenções do gênero, mas também as divergências, responsáveis por fazer uma narrativa única.

\section{AS NARRATIVAS DE ESCRAVOS}

A produção de narrativas sobre e no período de escravidão são muito ricas nos Estados Unidos. Já nos demais países a mericanos, essa produção é escassa, para não dizer nula. De acordo com Salles (2015, p. 9), em prefácio da edição brasileira da autobiografia de Juan Francisco Manza no (único trabalho do gênero na América Latina), o primeiro e principal motivo dificultador para que os escravos pudessem produzir esse tipo de texto é o a nalfabetismo:
Em primeiro lugar porque, em um mundo ainda em larga medida iletrado, no qual o percentual de cativos letrados nas sociedades escravistas americanas não deve ter alcançado a ordem de $1 \%$, os relatos autobiográficos de escravos africanos ou afrodescendentes são testemunhos raros. ${ }^{10}$

Podemos, então, perguntarmo-nos como os escravos norte-a mericanos tiveram tanto êxito em escrever suas histórias. Sabemos que muitas dessas autobiografias fora $\mathrm{m}$, na verdade, escritas por editores brancos, e trataremos desse aspecto mais adiante. Entretanto, várias narrativas trazem como próprio subtítulo a característica de "escrita por ele mesmo", como The Narrative of the Life of Frederick Douglass, an American Slave. Written by Himself (1845). Assim, o número de escravos alfabetizados parece ser maior nos Estados Unidos, uma vez que muitos textos são produzidos por eles. Uma explicação possível está na relação com os senhores. Como já mencionamos anteriormente, a hegemonia branca norte-americana acredita ser sua missão civilizar os inferiores e, portanto, algumas pessoas aventuram-se a ensinar os escravos a ler, com o propósito de capacitá-los na leitura da Bíblia. Geralmente, os escravos de casa, ou seja, mais próximos aos senhores, recebem tal possibilidade.

Em pouco tempo, o ato de ensinar o escravo a ler e escrever, aparentemente tão inofensivo, torna-se ilegal. Para Davis e Gates Jr. (1991) o escravo com essas habilidades

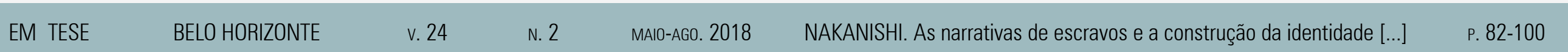

Teoria, Crítica Literária, outras Artes e Mídias 
11. DAVIS; GATES Jr. Introduction: the language of slavery, p. xxix. pode ser a meaçador, uma vez que "[1]er e escrever não era algo importante na vida do escravo. Aprender a ler e escrever significava que essa pessoa de descendência africana daria um passo gigantesco para a Grande Corrente do Ser; a 'coisa' torna-se um ser humano". ${ }^{11}$ Bauer, usando como exemplo a narrativa de Douglass, elucida como o aprender a escrever pode converter o homem:

Há uma segunda convenção que marca quase toda autobiografia afro-americana: a entrada para o mundo da leitura e da escrita. Quando Frederick Douglass era criança, sua ama começou a ensiná-lo a ler. O marido mandou, porém, que ela parasse: "O aprendizado não vai lhe fazer bem, mas lhe causar prejuízo", disse ele com severidade. "Se ensiná-lo a ler, ele vai querer saber como se escreve, e quando aprender isso, ele vai querer fugir com as próprias pernas”. Assim, as aulas terminaram, mas Douglass convenceu uma jovem branca, conhecida sua, a ensinar-lhe o alfabeto. Aprender a escrever foi uma espécie de conversão para Douglass, o ponto em que ele deu um passo para dentro de um novo mundo. Através da leitura, ele adquiriu um vocabulário que (como Douglass mesmo argumenta) "permitiu-me dar voz a muitos pensamentos interessantes que passavam pela minha cabeça e que estavam se extinguindo pela falta de palavras com as quais eu pudesse dar-lhes expressão”. E através da escrita ele ingressou no mundo branco não apenas como vítima, mas como testemunha e ativista. Escrever lhe deu poder até sobre seu passado de escravidão, de julgamento moral sobre os proprietários de escravos. "Eu não conseguia me satisfazer inteira mente só com narrar coisas erradas - sentia-me como se as estivesse denunciando", escreve ele. ${ }^{12}$

Dessa forma, é possível afirmar que a principal motivação para escravos produzirem as primeiras narrativas é a huma nidade que o ato de escrever representa. Os brancos norte-americanos declaram que os negros, por serem inferiores, não são capazes de uma atividade tão complexa como esta, pela suposta relação direta entre razão e inteligência com capacidade de escrever: "Desde a Renascença na Europa, o ato de escrever tem sido considerado um sinal visível da razão. Essa associação tem sido consistentemente invocada na teoria estética ocidental quando se discute a escravidão e o status dos negros" ${ }^{13}$

O escrever, então, é uma tentativa dos negros de provarem que também possuem inteligência e raciocínio e, portanto, são seres humanos: "A narrativa de escravos representa uma tentativa dos negros de passarem a existir por meio da escrita". ${ }^{14}$ Mas escrever sobre o quê? O tema mais natural e acessível para os escravos é a própria vida. De uma forma mais a mpla, as autobiografias podem ser encaradas como construção de uma identidade coletiva. A identidade africana é a mputada pelo homem branco e os negros
12. BAUER. $A$ história do eu: Biografias e memórias, p. 154

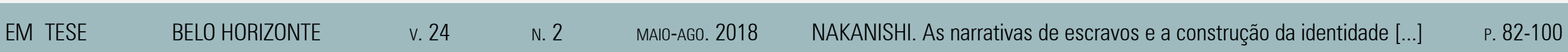

Teoria, Crítica Literária, outras Artes e Mídias 
15. DAVIS; GATES Jr. Introduction: the language of slavery, p. xxvi.

16. DAVIS; GATES Jr. Introduction: the language of slavery, p. xxvii. são rotulados como não possuidores de uma História. Ao escrever sobre suas vidas, semelhantes às de muitos outros negros, os escravos formam uma visão panorâmica a respeito de seu modo de vida enquanto povo:

Acusados de não possuírem uma história coletiva e formal, os negros publicaram histórias individuais que, juntas, deviam narrar, em segmentos, a grande e fragmentada história dos negros na África, então dispersos pelo frio Novo Mundo. O "olho" descritivo narrado foi colocado em uso como uma forma literária tanto para o "eu" individual do autor negro, como o "eu" coletivo da raça. Os textos criavam autores, e autores negros esperavam criar, ou recriar, a imagem da raça no discurso europeu. A própria face da raça, representações das características que eram comuns em todo tipo de escrita sobre negros naquele tempo, foi contingente sobre o registro da $v o z$ negra. Voz pressupõe uma face, mas também parece ter determinado o contorno da face negra. ${ }^{15}$

Além de registrar o passado, tais textos ta mbém têm o poder de trazer novas perspectivas para o futuro. Para Davis e Gates Jr., "[a] voz no texto era verdadeiramente uma voz milenar para o africa no letrado no século XVIII, porque essa era a voz da libertação e da redenção que significariam uma nova ordem para o negro" ${ }^{16}$ Uma vez tendo refletido sobre o passado e, com isso, tendo reconquistado sua humanidade, o ex-escravizado mostra a capacidade "de prosperar na sociedade moderna". ${ }^{17} \mathrm{O}$ desejo de mostrar ser um indivíduo completo, que, mesmo não tendo bens físicos, possui algo: a própria história e, doravante, a própria vida. Assim, tenta demonstrar enquadrar-se, de certa forma, no pensamento individualista incutido pela democracia, e afastar-se da imagem do Outro, embora hoje possamos perceber o quão difícil, para não dizer impossível, seja tal tarefa.

De acordo com Bauer, "[o]s escritores de autobiografias aplicam certas técnicas. Eles não só reestruturam o passado de uma maneira que faça sentido no presente, mas também seguem certas convenções ao na rrar a sua vida". ${ }^{18}$ Para a autora, os primeiros autores negros seguem a forma que os autores brancos usavam para se validarem dentro do gênero autobiográfico. Ela explica, por exemplo, que a maior parte das narrativas de ex-escravos começa o texto contando a origem familiar, ainda que seja, muitas vezes, misteriosa (já que crianças são vendidas e separadas de seus pais ainda muito jovens para lembrar-se). Eles sentem a necessidade de fazê-lo justamente porque as autobiografias de homens brancos começam dessa forma:

Todavia, enquanto a família de [Benjamin] Franklin lhe havia proporcionado um protótipo de si mesmo (seus
17. GOULD. The economics of the slave narrative, p. 101.
EM TESE
BELO HORIZONTE
v. 24
N. 2
MAIO-AGO. 2018
NAKANISHI. As narrativas de escravos e a construção da identidade [...]
P. $82-100$

Teoria, Crítica Literária, outras Artes e Mídias 
ancestrais eram homens livres, que valorizavam a leitura e a escrita e se recusavam a baixar a cabeça diante de autoridades religiosas abusivas), a família de [Frederick] Douglass não participa do resto da sua história. Por que, então, ele começa com o seu nascimento e ascendência? Porque embora nunca tenha lido nenhum livro sobre a arte de escrever uma autobiografia, havia lido outras histórias de vida, e a leitura o conscientizou de que uma autobiografia "apropriada" começa com o nascimento e ancestralidade familiar. Trata-se de uma convenção da autobiografia. ${ }^{19}$

A partir dos elementos comuns com a autobiografia do homem branco, contudo, as narrativas do negro começam a ter características próprias que as diferenciam. Ainda para Bauer, as autobiografias dos negros distanciam-se das dos brancos no "reconhecimento da negritude", pois é nesse momento que sua história se inicia (em vez do nascimento, como nas autobiografias dos brancos):

Contudo, o começo real da história acontece pouco depois, em um evento que se tornou uma convenção da autobiografia negra, o reconhecimento da negritude. Todo escritor afro-americano vê-se a si mesmo simplesmente como uma pessoa - até chegar a um ponto da infância em que ele é visto com desdém ou horror por alguma outra pessoa. Nesse momento, o "eu" não se vê mais como "normal", mas como diferente, como negro. Desse momento em diante, o autobiógrafo afro-americano se confronta com uma visão dupla. Como o autobiógrafo branco, ele tenta criar-se a si mesmo nas páginas do seu livro, mas ao fazer isso, ele não consegue deixar de ver-se através dos olhos hostis dos outros. A negritude torna-se (nas palavras de Roger Rosenblatt), tanto em sua identidade quanto em seu destino trágico, uma "condição que prescreve e predetermina a vida". ${ }^{20}$

Essas características começam, assim, a modelar o gênero das na rrativas de escravos. De acordo com Olney (1984), elas seguem um formato rigidamente fixo. Isso acontece porque tais textos têm como objetivo primeiro relatar a escravidão "como ela é", em um "[p]lano mestre para narrativas de escravos", ${ }^{21}$ envolvendo o ex-escravo, o patrocinador e o público, em um relaciona mento triangular. Assim, Olney afirma que os elementos fixos são a garantia das narrativas alca nçarem o objetivo abolicionista. Toma mos como exemplo o uso da dimensão episódica. Para não serem questionados quanto à veracidade dos fatos, os escritores (e editores) de autobiografias de ex-escravos tentam ao máximo evitar a imaginação e a criatividade, pois contar os eventos como episódios assegura um relato mais objetivo e sem floreios. Além disso, essa técnica permite que o ex-escravo possa se colocar mais imediatamente dentro da história, narrando o sentido e o visto, como se ainda estivesse vivendo tal momento.
20. BAUER. A história do eu: autobiografias e memórias, p. 154

21. OLNEY. "I was born": slave narratives, their status as autobiography and as literature, $p$.

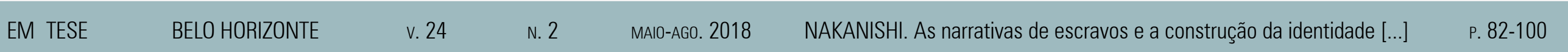

Teoria, Crítica Literária, outras Artes e Mídias 
O triângulo formado por ex-escravo, patrocinador e público, mencionado há pouco, influencia diretamente o formato rígido das narrativas de escravos. $\mathrm{O}$ ex-escravo é, obviamente, fundamental para o texto, pois é o tema e o conteúdo. Já os patrocinadores, na maior parte dos casos (mas não somente), editores associados ao movimento abolicionista, têm intenções específicas para o trabalho: sensibilizar as pessoas do norte sobre os horrores da escravidão e humanizar o homem negro aos olhos dos brancos. Ou seja, o público (terceira ponta do triângulo) já está na mente do escritor mesmo antes de produzir o texto. Ainda de acordo com Olney (1984), "[a]ssim, em certo sentido, as vidas narradas dos ex-escravos eram tão possuídas e usadas pelos abolicionistas como as vidas vividas o eram pelos senhores de escravos." 22 Uma vez narradas, as histórias deixam de pertencer ao ex-escravo e o editor passa a ter direito de moldá-las da forma que mais lhe pareça frutífera. Com isso em mente, é compreensível que os textos acabem tão semelhantes entre si.

Para Roy (2015), entretanto, não devemos generalizar as narrativas de escravos como panfletagem abolicionista. Apesar da maior parte estar, de fato, envolvida com o movimento, muitos outros textos partem de outras origens e têm outros objetivos:
Algumas [narrativas] estavam profundamente embutidas no discurso abolicionista, enquanto outras eram primariamente oportunidades comerciais feitas para lucrar com o frenesi do "Uncle Tom" da década de 1850. Algumas eram extremamente populares, mas várias narrativas produzidas localmente não eram - e não eram para ser. A maioria era direcionada para o público do norte, mas cópias de algumas narrativas circularam pelo sul. ${ }^{2.3}$

O autor afirma que depois do sucesso do livro de Harriet Beecher Stowe, algumas a utobiografias são editadas fora do círculo abolicionista para um público desejando apenas entretenimento. Roy ainda explica que pouco sabemos sobre a recepção do gênero, mas é possível a firmar que, além do público certo no norte, alguns livros ta mbém encontram seu lugar entre sulistas.

Cada autobiografia, portanto, percorre caminhos diferentes. Roy lembra que o livro de James Williams, Narrative of James Williams, an American Slave (1838), é publicado pela AASS (organização abolicionista), com grande circulação, enqua nto o de Douglass, Narrative of the Life of Frederick Douglass, an American Slave (1845), é publicado pelo próprio esforço do autor, tendo que vender ele mesmo seus livros, até conseguir reconhecimento (e, consequentemente, patrocinadores). Já o livro de Solomon Northup, 12 anos de escravidão, sobre o qual discorreremos de forma mais específica
23. ROY. Cheap editions, little books, and handsome duodecimos. a book history approach to antebellum slave narratives, p. 70.

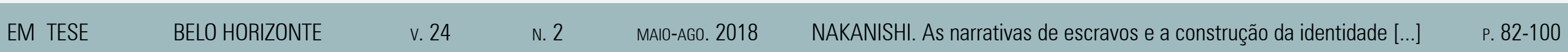

Teoria, Crítica Literária, outras Artes e Mídias 
24. ROY. Cheap editions, little books, and handsome duodecimos: a book history approach to antebellum slave narratives, p. 784

25. GATES Jr.; MCKAY. The Norton anthology of African American literature, p. 158 a seguir, é publicado em 1853 por uma grande editora sem vínculos com o movimento abolicionista. De acordo com Roy, trata-se de um livro de luxo:

De um ponto de vista puramente prático, nem todos podiam pagar um livro como 12 anos de escravidão, que custava quatro vezes mais do que uma cópia da Narrativa da vida de Frederick Douglass. De forma similar, comprar uma cópia de 12 anos de escravidão não pressupunha qualquer familiaridade com o movimento contra a escravidão. ${ }^{24}$

Podemos afirmar que as narrativas de escravos chegam a ser lucra tivas, tornando o mercado editorial dessas obras muito mais complexo do que imaginamos: "De 1830 até o fim da era escravista, a narrativa de escravos fugidos dominou o panorama literário da América negra pré-guerra, superando o número de autobiografias de pessoas negras livres, sem mencionar a grande quantidade de romances publicados por afro-a merica nos." ${ }^{25}$

Não devemos esquecer, entretanto, que o estabelecimento do gênero se deve ao esforço de pequenas editoras abolicionistas no norte dos Estados Unidos:

Negros livres do norte davam apoio à Sociedade Anti-Escravista Americana de Garrison, editando jornais, realizando convenções, circulando petições e investindo seu dinheiro e energia em protestos. Procurando formas de galvanizar a preocupação do público para com o escravo como "um homem e um irmão”, essa geração de abolicionistas radicais, negros e brancos, patrocinou uma nova vertente na era afro-americana, a narrativa de escravos fugidos. ${ }^{26}$

Possuímos, portanto, evidências que nos possibilitam enxergar a origem do gênero e seu desenvolvimento na época em que o sistema escravagista é vigente. Reconhecemos, ta mbém, seu valor literário e histórico na atualidade. Contudo, o entremeio desde o fim da escravidão até recentemente parece-nos mais nebuloso. A maior parte dos estudiosos sobre o tema concorda que as narrativas de escravos caíram em um tipo de abismo literário, sendo menosprezadas como literatura. Isso se deve, principalmente, pela desvalorização do gênero autobiográfico, que parece só reconquistar seu lugar de interesse entre os críticos na década de 1950

A razão por que a autobiografia se tornou um tópico para a investigação crítica, de uma hora para a outra, nos anos de 1950, nunca foi explicada, mas - como a maior parte dos fenômenos de meados de século - esse novo interesse provavelmente teve algo a ver com o trauma do pós-guerra. Roy Pascal reivindicava que a autobiografia pode ser um caminho para a descoberta de uma verdade mais verdadeira do
26. GATES Jr.; MCKAY. The Norton anthology of African American literature, p. 158.
EM TESE
BELO HORIZONTE
v. 24
MAIO-AGO. 2018
NAKANISHI. As narrativas de escravos e a construção da identidade [...]
P. $82-100$

N. 2

Teoria, Crítica Literária, outras Artes e Mídias 
27. BAUER. A história do eu: autobiografias e memórias, p. 151. que o fato histórico, porque ele viveu em tempos em que as pessoas sensatas ansiavam pela vitória sobre os fatos históricos (aquele registro de puras chacinas e holocausto). A ideia de que o crítico, olhando para os fatos pela lente da história de uma vida, pudesse encontrar uma verdade mais profunda para além deles deve ter parecido bela e incrivelmente promissora. $^{27}$

A redescoberta das a utobiografias de ex-escravos, especificamente, acontece cerca de uma década depois do início da valorização das a utobiografias em geral. Roy afirma que, para serem validadas como objeto de estudo, as narrativas de escravos são consideradas um único corpo coerente, o que limita as possibilidades de leitura e análise de tais textos:

Mesmo durante a então chamada era de ouro, as narrativas de escravos não constituíam um gênero monolítico. A redescoberta das narrativas de escravos, nos anos 1960, e a sua assimilação no cânone literário talvez não tivessem sido possíveis sem a edificação de um monólito: narrativas de ex-escravos precisavam ser apresentadas como um corpo de textos uniformes, facilmente apreensíveis com um número vasto de leitores para poderem ser aceitas como objeto de estudo legítimo. Agora, entretanto, é hora de uma "desagregação criativa” do gênero defendido por Gardner ('Slave
41) e Goddu. Os próprios Noah Davis e Frederick Douglass, como citados nas epígrafes deste ensaio, sugerem uma forma de atingir isso: concentrando-nos nas formas concretas com que cada autor de narrativas de escravos, com ou sem a ajuda de assistentes, ativistas abolicionistas ou editoras comerciais, realmente "fizeram livros". ${ }^{28}$

Entendemos, assim, que o gênero narrativa de escravos é muito mais complexo do que podemos imaginar em um primeiro olhar. $\mathrm{O}$ assunto é amplo e grande parte do material sobre ele encontra-se disponível nos Estados Unidos. Neste trabalho, não chega mos, nem de perto, a esgotar o assunto. $\mathrm{Na}$ próxima seção, procuraremos discutir mais aspectos das autobiografias de ex-escravos e aprofundar-nos nas questões que se mostrarem mais pertinentes, concentrando-nos, como sugere Roy, especifica mente em um livro e em um autor, sendo eles, 12 anos de escravidão e Solomon Northup.

\section{O CASO DE 12 ANOS DE ESCRAVIDÃO, DE SOLOMON}

\section{NORTHUP}

Escrita e publicada em 1853, a autobiografia de Solomon Northup, 12 anos de escravidão (12 Years a Slave, no original em inglês) possui o seguinte subtítulo: "Na rrativa de Solomon Northup, cidadão de Nova York, sequestrado na cidade de Washington em 1841, e resgatado em 1853, de uma plantação de algodão perto do Rio Vermelho na
28. ROY. Cheap editions, little books, and handsome duodecimos. a book history approach to antebellum slave narratives, p. 86.

Teoria, Crítica Literária, outras Artes e Mídias 
29. ROY. Cheap editions, little books, and handsome duodecimos: antebellum slave narratives, p. 80
Louisiana”. Um aparente resumo do enredo, tal subtítulo, recurso emprestado do romance inglês e muito usado pelas narrativas de escravos, tem a função de passar credibilidade da história e de seu autor ainda na capa do livro. Como discutimos anteriormente, as autobiografias de ex-escravos são obrigadas a comprovar a própria veracidade para serem levadas a sério no círculo abolicionista. Já no caso de 12 anos de escravidão, Roy (2015) afirma que o livro é lançado no círculo editorial de entretenimento, e não há envolvimento direto com o movimento contra escravidão

Quando publicado em 1854, 12 anos de escravidão. Narrativa de Solomon Northup, um cidadão de Nova York, sequestrado em Washington em 1841, e resgatado em 1853, de uma plantação de algodão perto de Rio Vermelho, na Louisiana foi a primeira narrativa a ser publicada sob o selo de uma casa editorial comercial - chamada Derby and Miller, uma firma que tinha conseguido certo sucesso através de publicações de biografias, histórias padrões e livros educacionais e de direito [...]. ${ }^{29}$

Mesmo distanciando-se das demais edições de narrativas de escravos quanto à sua editoração/ publicação, 12 anos de escravidão mantém as características do gênero, como o previamente mencionado subtítulo na capa. Outra convenção do gênero é o uso de ilustrações. As editoras da época acreditam ser importante, por tratar-se de uma autobiografia, dar um rosto à voz narrativa. No caso do retrato de Solomon
Northup, um aspecto que parece cha mar a atenção de muitos é a fisionomia calma e contemplativa demonstrada, destoando do clima pesado e tenso do enredo da história.

Além disso, as ilustrações ta mbém servem como comprovação de que o autor realmente existe (muitos anti-abolicionistas questionam a veracidade de todos os fatos narrados, incluindo, muitas vezes, a própria existência do ex-escravo). Nova mente, 12 anos de escravidão vai ao encontro das convenções do gênero. Entretanto, podemos apontar um maior investimento editorial, visto que a edição da Derby and Miller possui nada menos do que sete ilustrações ao decorrer da narrativa. De acordo com Pope:

As ilustrações de 12 anos de escravidão eram específicas à narrativa de Northup, mas elas ta mbém criava m um vocabulário visual da escravidão e de imagens anti-escravistas uma área que muitos acadêmicos vêm a AAS [The American Antiquarian Society] estudar. Este vocabulário poderia ser utilizado por editores para ajudar a vender o livro. ${ }^{30}$

Ademais, tal edição ainda dispõe de outros paratextos: uma dedicatória a Harriet Beecher Stowe; um índice detalhado do conteúdo; um trecho do poema "The Task", de William Cowper (1731-1800); a partitura da música "Roaring River"; e uma seção de apêndices contendo diversas partes de documentos que comprova $m$ a autenticidade de determinados episódios narrados.

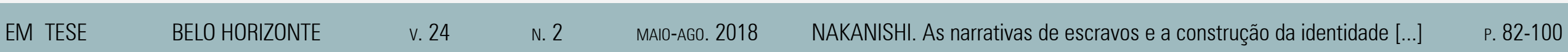

Teoria, Crítica Literária, outras Artes e Mídias 
31. ROY. Cheap editions, little books, and handsome duodecimos:
a book history approach to antebellum slave narratives, p. 81
A dedicatória de Solomon Northup, em especial, nos interessa: "Para Harriet Beecher Stowe: cujo nome, em todo o mundo, é identificado com a grande reforma: esta narrativa, proporciona ndo outra Chave para A Cabana do Pai Tomás, é respeitosamente dedicada". Como já comenta mos, 12 anos de escravidão é uma tentativa da editora Derby and Miller de entrar no frenesi que A Cabana do Pai Tomás (1852), de Harriet Beecher Stowe, causara. Por mais caridosos que Derby e Miller tenham sido ao lidar com Northup, a publicação da história de 12 anos de escravidão ainda estava ligada de forma intricada à Cabana do Pai Tomás e à moda que era conhecida como "literatura do Pai Tomás". 31

De acordo com Roy, o romance de Stowe, mesmo sendo uma ficção, influencia a forma como diversos episódios da história de Solomon são narrados. Acreditamos, entretanto, que a influência de Stowe não tenha sido direta em Solomon. Tendo sido resgatado em 1853 e publicado ainda no mesmo ano, parece-nos pouco provável que Solomon tenha conseguido, em tão pouco tempo, inteirar-se das ondas literárias do momento. O editor David Wilson, que, de fato, coloca as memórias de Solomon no papel, muito provavelmente está mais a par das tendências editoriais e tem uma intimidade maior com o texto de Stowe. Portanto, a dedicatória de 12 anos de escravidão parece-nos mais uma escolha editorial para atrair o mesmo público que $A$ Cabana do Pai Tomás do que um laço emocional de Northup em relação à autora. Acredita mos que os paratextos são estratégias editoriais e pouco parecem ser escolhas do próprio Solomon, assim como o estilo da narrativa.

Divididos em vinte e dois capítulos, os acontecimentos são narrados como se Solomon os estivesse revivendo, prática usual nas narrativas de escravos. Temos, portanto, um relato em primeira pessoa, o que permite assumir pausas no enredo para comentários críticos. Como sabemos, Solomon Northup nasce homem livre e assim vive pelos primeiros trinta e três anos. Por ter conhecido a vida fora do cativeiro, consegue observar o sistema escravagista de uma perspectiva diferente dos companheiros escravos. Em certos momentos, a té mesmo a nalisa o comportamento de quem nasce em tal condição:

Mary, uma mocinha alta, com um cabelo preto como azeviche, era apática e parecia indiferente. Como muitos de sua classe, mal sabia da existência da palavra "liberdade". Criada à sombra da ignorância de um homem rude, ela tinha pouco mais que a inteligência de uma pessoa rude. Era uma daquelas pessoas, como há muitas, que nada temem a não ser o chicote de seu senhor e que não conhecem nenhuma outra obrigação senão obedecer à voz dele. ${ }^{32}$
32. NORTHUP. Doze anos de escravidão, p. 52. 
Podemos observar que, em momentos descritivos, mesmo em primeira pessoa, Solomon mantém certa distância quando assume uma atitude analista. Os escravos, como Mary, são o Outro e parecem nem mesmo pertencer à saga do herói-narrador; são importantes enqua nto argumentos e contrastes com a história do homem livre injustiçado. Assim, o foco narra tivo oscila durante a narrativa: existem dois narradores, o a utodiegético, em episódios que afetam Solomon diretamente, e o heterodiegético, em momentos em que se afasta dos acontecimentos para a nalisá-los, quase como se olhando de fora. No trecho acima, por exemplo, ao usar "[c]omo muitos de sua classe" e "[e]ra uma daquelas pessoas, como há muitas," Solomon posiciona-se como diferente. Além disso, pouco interage com os outros escravos, com exceção de Patsey, e isso fica evidente com a oscilação do narrador. Essa alternância permite que a narrativa de Solomon apresente diversas impressões e opiniões. Mesmo nos primeiros capítulos, mostrando-se um narrador a utodiegético, ele observa criticamente as próprias atitudes do período prévio da vida:

Quando morávamos no United States Hotel, eu frequentemente encontrava escravos que haviam acompanhado seus senhores desde o Sul. Estavam sempre bem vestidos e bem cuidados, levando o que parecia ser uma vida fácil, com poucos problemas a importuná-los. Muitas vezes conversavam comigo sobre a Escravidão. Parecia-me que quase todos eles acalentavam um desejo secreto de liberdade. Alguns expressavam a mais ardente vontade de fugir e me perguntavam o melhor método de fazê-lo. O medo da punição, porém, que eles sabiam que os esperava quando de sua recaptura e retorno, bastava para demovê-los da experiência. Tendo durante toda a minha vida respirado o ar livre do Norte e consciente de que eu tinha os mesmos sentimentos e afeições que encontram lugar no peito de um homem branco, consciente, além disso, de ter uma inteligência igual à de pelo menos muitos homens de pele mais clara, eu era ignorante demais, talvez independente demais, para entender como alguém poderia se contentar em viver na condição abjeta de escravo. ${ }^{33}$

Ao falar sobre os escravos, Solomon distancia-se: "Muitas vezes conversavam comigo sobre a Escravidão", isso indica um interesse unilateral na conversa, ou melhor, um desinteresse por parte de Solomon. "Muitas vezes conversávamos sobre a Escravidão" colocaria Solomon em um papel ativo na discussão, o que não acontece, deixando aparente o desejo de não se envolver. Mostra-se quase heterodiegético. Logo em seguida, qua ndo fala sobre a liberdade, Solomon discursa com paixão, demonstra opiniões e sentimentos intensos, pois o conceito de liberdade sim the diz respeito. Faz-se a utodiegético. Assim, a escravidão e os escravos são
33. NORTHUP Doze anos de escravidão, p. 23.

EM TESE BELO HORIZONTE $\quad$ v. $24 \quad$ N. 2 MAIO-AGo. 2018 NAKANISHI. As narrativas de escravos e a construção da identidade [...] $\quad$ P. 82-100

Teoria, Crítica Literária, outras Artes e Mídias 
uma realidade à qual não deseja pertencer, nem mesmo interiorizar. Isso acontece durante toda a narrativa, mesmo posteriormente, quando obrigado a viver essa realidade.

Solomon dedica muitas passagens de sua narrativa como a totalidade do capítulo 12 e partes dos capítulos seguintes, a pormenorizar o funcionamento da plantação de algodão e a vida dos escravos. Um dos temas explorados no Solomon em tal detalha mento é a distribuição de comida dentro da fazenda. De acordo com ele, até os porcos têm prioridade na alimentação, pois recebem milho debulhado para serem engordados, enqua nto os escravos mal recebem espigas de milho e, portanto, tornam-se responsáveis pela própria alimentação e consequente sobrevivência:

A ração semanal de comida mal bastava para nos satisfazer. Era costume entre nós, como entre todos naquela região, onde a ração termina antes do sábado à noite ou então fica num estado nauseabundo e nojento, caçar guaxinim e canga mbás nos brejos. Isso, porém, precisa ser feito à noite, depois que o trabalho do dia é terminado. Há fazendeiros cujos escravos passam meses sem nenhuma outra carne senão a que é obtida desse jeito. Nenhuma objeção é feita ao ato de caçar, ainda mais que poupa o defumadouro e cada guaxinim desatento que é morto significa um tanto poupado do milho armazenado. Eles são caçados com cães e tacos, já que escravos não têm permissão para usar armas de fogo. ${ }^{34}$

Além das descrições sobre os aspectos desumanizadores, Solomon intenciona descrever a vida na fazenda como realmente é, pois não exclui os momentos "felizes" (ou os momentos não tão terríveis) ao relatar, por exemplo, o período de três dias em que os escravos têm direito a descanso no período do Natal:

Nessas ocasiões eles são vistos indo apressados em todas as direções, os mortais mais felizes que se podem ver na face da Terra. São seres diferentes do que quando estão nos campos; o descanso temporário, o breve intervalo do medo e do açoite, produz uma completa metamorfose em sua aparência e atitude. $^{35}$

Pela primeira vez em seu relato, Solomon enxerga os colegas escravos como seres humanos. Ele reconhece a diferença que - menos a nimalizados e objetificados - permite, também pela primeira vez, encará-los como semelhantes. Sentimos empatia de modo diferente, não como sentimos por um animal com dor, mas como sentimos por outro ser humano em sofrimento. Relatar episódios felizes na vida da fazenda, entretanto, não o torna complacente com o sistema escravagista. Ao contrário, momentos felizes trazem
34. NORTHUP. Doze anos de escravidão, p. 162

35. NORTHUP. Doze anos de escravidão, p. 178. 
36. NORTHUP. Doze anos de escravidão, p. 173.

37. NORTHUP. Doze anos de escravidão, p. 178-9.

38. OLNEY. "I was born": slave narratives, their status as autobiography and as literature, $p$. huma nidade aos escravos, fazendo com que o leitor possa relacionar-se à figura desses seres capazes de sentir tanto qua nto qualquer outro. Temos, por exemplo, o trecho a seguir, no qual Solomon afirma que o Cupido trabalha de forma similar entre brancos e negros:

Duas pessoas entre as quais haja alguma troca afetiva invariavelmente dão um jeito de sentar uma na frente da outra [na ceia de Natal]; pois o onipresente Cupido não deixa de lançar suas setas no coração simples dos cativos. ${ }^{36}$

Consequentemente, momentos de felicidade intensificam a contraposição aos momentos de sofrimento: "Assim é a 'vida sulista como ela é, três dias por ano, tal como a vi - os outros trezentos e sessenta e dois sendo dias de exaustão, medo, sofrimento e infindável trabalho". ${ }^{37}$ Para Olney (1984), contudo, passagens como essas exibem o estilo de Wilson:

Talvez uma melhor instância do escritor branco/ novelista sentimental que colocou seu estilo polido sobre a história fiel, tal como recebida dos lábios de Northup, seja encontrada nesta descrição de uma celebração de Natal em que uma enorme refeição foi fornecida por um proprietário de escravos para escravos de plantações dos arredores [...]. ${ }^{38}$
Gostaría mos de ressaltar, por outro lado, que durante a descrição da vida na fazenda, a oscilação da posição do narrador é evidente, pois se trata de uma porção da narrativa da qual Solomon se distancia. Talvez ele o faça por acreditar que assim poderia fornecer um relato mais objetivo. Entretanto, não podemos deixar de sentir certo conflito interno na narração, como se ele não passasse pela mesma rotina que os demais escravos. Não temos, por exemplo, nenhum evento que envolva Northup na descrição de celebração de Natal.

Mais adiante, quando Solomon é resgatado, a questão da identidade vem à tona. Ainda na casa de escravos em Washington, Solomon aprende que, em sua nova condição, a verdade poderia ser perigosa. Assim, Burch convence-o, com torturas, a assumir uma nova identidade. Durante os doze anos em cativeiro, junto com sua identidade de homem livre nascido no norte do país, seu nome real ta mbém lhe é negado. Portanto, ninguém na região do Rio Vermelho conhece-o por Solomon Northup, mas sim por Platt, o escravo. O leitor, ainda no começo da narrativa, provavelmente sente-se impactado pela forma como a identidade é arrancada de Solomon; entretanto, conforme a história progride, a situação acaba suavizando-se, pois quem nos fala é o Solomon narrador, o homem livre, e não o escravo Platt. Acabamos, portanto, esquecendo-nos desse conflito

EM TESE BELO HORIZONTE $\quad$ v. $24 \quad$ N. 2 MAIO-A60. 2018 NAKANISHI. As narrativas de escravos e a construção da identidade [...] $\quad$ P. 82-100

Teoria, Crítica Literária, outras Artes e Mídias 
39. NORTHUP. Doze anos de escravidão, p. 243-4. e de suas consequências. É no resgate de Solomon que realmente sentimos os impactos dessa "dupla identidade" no exterior, pois, a té então, o conflito ocorre de forma interna, já que apenas ele tinha conhecimento da própria origem:

Os escravos, totalmente confusos, ficaram observando a cena, boquiabertos e com olhos atentos indicando grande confusão e surpresa. Durante dez anos eu vivera entre eles, no campo e na cabana, suportara as mesmas provações, partilhara a mesma comida, misturara minhas tristezas com as suas, participara das mesmas poucas alegrias; ainda assim até aquele momento, o último em que eu estaria entre eles, não faziam a menor ideia de meu nome verdadeiro, tampouco era de seu conhecimento qualquer informação sobre minha verdadeira história. ${ }^{39}$

$\mathrm{Na}$ cena do resgate somos lembrados que o homem que vive na fazenda de Epps é Platt e não Solomon. Os seus companheiros nunca poderiam imaginar que uma pessoa livre se encontra entre eles, na mesma condição. As questões do Outro tornam-se ainda mais complexas, pois Solomon não pertence, de fato, a nenhuma das realidades: quando livre, é um negro entre brancos; quando sequestrado, é um homem livre entre escravos.

\section{CONSIDERAÇÕES FINAIS}

A autobiografia de Solomon confirma a afirmação de Roy de que não devemos ler as narrativas de escravos como um bloco monolítico. De diversas maneiras, como tentamos explicitar, 12 anos de escravidão segue as convenções do gênero, corroborando, portanto, as demais narrativas do gênero, e colaborando, mesmo que indireta mente, com o movimento abolicionista e a construção da identidade coletiva afro-a mericana. Por outro lado, por tratar-se da história de um homem nascido livre, as perspectivas e críticas fazem-se relativa mente diferentes. Entretanto, ele não deixa de passar pelos mesmos episódios que os demais escravos nos doze anos que vive como um. Há, dessa forma um confronto entre essas duas identidades. Suas descriç̃es demonstram tal a mbivalência, uma vez que, como dissemos anteriormente, ele não pertence completamente a nenhuma das duas identidades. Podemos afirmar, finalmente, que as narrativas de escravos são fundamentais dentro da literatura afro-americana e, claro, mundial. Com isso enfim estabelecido pela crítica recente, aconselhamos um tratamento e uma leitura individuais de cada obra, para que seja possível extrair o que elas têm de especial e único. 


\section{REFERÊNCIAS}

THE Abolition of the slave trade. New York: The New York Public Library, c2012. Disponível em: < http://abolition.nypl.org/> Acesso em: 28 nov. 2017

BAUER, Susan. A história do eu: autobiografias e memórias. In Como educar sua mente: O guia para ler e entender os grandes autores. São Paulo: É Realizações Editora, 2015. p. 143173.

BOSI, Alfredo. Ideologia e contraideologia. São Paulo: Companhia das Letras, 2010.

COOMBS, Norman. The shape of American slavery. In: The black experience in America. [S. 1.], Project Gutenberg eBook, 2008. Disponível em: <http://www.gutenberg.org/ files/67/67-h/67-h.htm> Acesso em: 14 abr. 2016.

DAVIS, Charles.; GATES JR., Henry Louis. Introduction: the language of slavery. In: The slave's narrative. New York: Oxford University Press, 1991. p. xi-xxxiv.

GATES JR., Henry Louis.; MCKAY, Nellie. The Norton anthology of African American literature. New York: W. W. Norton \& Company, 2004.

GOULD, Philip. The economics of the slave narrative. In JARRETT, Gene Andrew. (Ed.). A Companion to African American literature. Hoboken: Wiley Blackwell, 2010. p. 90-102.

NORTHUP, S. Doze anos de escravidão. Tradução: Caroline

Chang. São Paulo: Penguin Classics Companhia das Letras, 2014
OLNEY, James. "I was born": slave narratives, their status as autobiography and as literature. Callaloo, Baltimore, n. 20, p. 4673, 1984.

POPE, E. W. Twelve Years a Slave, the Book: dramatizations, illustrations \& editions. Past is present: the American antiquarium society blog, Worcester, 2014. Disponível em: $<$ http://pastispresent.org/2014/good-sources/twelve-years-aslave-the-book-dramatizations-illustrations-editions/>. Acesso em: 3 jan. 2017.

ROY, Michäel. Cheap editions, little books, and handsome duodecimos: a book history approach to antebellum slave narratives. MELUS, Cary, v. 40, n. 3, p. 69-93, 2015.

SALLES, Ricardo. Prefácio. In: MANZANO, Juan Francisco. A autobiografia do poeta-escravo. São Paulo: 2015. p. 9-12.

Recebido em: 13-08-2018 Aceito em: 20-11-2018. 